\title{
PENINGKATAN HASIL BELAJAR MATEMATIKA SISWA DENGAN PENERAPAN MODEL PEMBELAJARAN PROBLEM POSING DI KELAS VIII SMP NEGERI 5 TANAH GROGOT TAHUN AJARAN 2017/2018
}

\author{
Supriaten \\ SMP Negeri 5 Tanah Grogot
}

\begin{abstract}
ABSTRAK
Penelitian ini adalah penelitian tindakan kelas dengan tujuan untuk mengetahui peningkatkan hasil belajar matematika siswa kelas VIII-A SMP Negeri 5 Tanah Grogot melalui model pembelajaran problem posing pada materi pokok fungsi dan persamaan garis lurus. Penelitian dilaksanakan di SMP Negeri 5 Tanah Grogot tahun ajaran 2017/2018 dengan subjek penelitian adalah siswa kelas VIII-A yang berjumlah 35 siswa dan objek penelitian adalah pembelajaran problem posing tipe post solution posing. Teknik pengumpulan data dengan observasi, tugas, dan tes. Penelitian dilaksanakan dalam 3 siklus yang masing-masing dilaksanakan tiga kali pertemuan. Teknik analisis yang digunakan adalah analisis kualitatif untuk menganalisis hasil observasi dan analisis kuantitatif untuk menganalisis tugas dan tes yang sesuai dengan indikator peningkatan yang telah ditentukan dengan menggunakan statistik deskriptif berupa rata-rata, persentase, dan grafik. Persentase peningkatan nilai sebesar 72,57\% dan persentase ketuntasan sebesar $11,43 \%$. Adapun persentase peningkatan nilai siklus I ke siklus II yaitu $24,35 \%$ dan persentase ketuntasan sebesar 54,28\%. Demikian pula peningkatan persentase peningkatan nilai siklus II ke siklus III adalah 7,99\% dan persentase ketuntasan sebesar $82,86 \%$. Aktivitas guru pada siklus I dinilai cukup, siklus II dinilai sangat baik dan siklus III dinilai sangat baik sedangkan aktivitas siswa pada siklus I dinilai sangat kurang, siklus II dinilai baik dan siklus III dinilai sangat baik. Dengan demikian, melalui penerapan model pembelajaran problem posing tipe post solution posing hasil belajar matematika siswa pada materi pokok fungsi dan persamaan garis lurus kelas VIII-A SMP Negeri 5 Tanah Grogot mengalami peningkatan.
\end{abstract}

Kata Kunci: Peningkatan Hasil Belajar Siswa dan Model Problem Posing

\section{PENDAHULUAN}

Pendidikan merupakan salah satu kebutuhan hidup yang sangat penting saat ini. Hal ini sangat mendasar mengingat pendidikan dijadikan salah satu tolak ukur tingkat kesejahteraan manusia. Berkualitas tidaknya seseorang dipengaruhi oleh sejauh mana kualitas pendidikan yang didapat di bangku sekolah atau masyarakat. Adanya peningkatan dan perkembangan mutu pendidikan merupakan hal mutlak untuk dilakukan disetiap jenjang pendidikan karena keberhasilan suatu negara ditentukan dari kualitas SDM sedangkan keberhasilan SDM sangat ditentukan oleh pendidikannya. Tuntutan dunia semakin kompleks mengharuskan siswa berfikir kritis, sistematis, logis, kreatif, bernalar dan kemauan kerjasama yang efektif.

Matematika merupakan salah satu cabang ilmu yang sangat penting, dimana matematika diajarkan mulai dari jenjang Sekolah Dasar sampai Perguruan Tinggi. Matematika sangat berperan dalam memajukan pendidikan. 
Matematika sebagai salah satu ilmu dasar, dewasa ini telah berkembang pesat, baik materi maupun kegunaannya.

Sebagaimana pernyataan

Hudoyo (dalam Herawati, 2010:71) bahwa matematika berkenaan dengan ide-ide dan konsep-konsep yang abstrak dan tersusun secara hierarki dan penalarannya deduktif. Adanya konsepkonsep dan penalaran dalam matematika, menjadikan salah satu mata pelajaran yang cukup sulit. Hal ini terlihat dari hasil belajar siswa yang dicerminkan melalui nilai hasil belajar matematika siswa yang banyak tidak mencapai kriteria ke-tuntasan minimum (KKM). Seperti yang terjadi di SMP Negeri 5 Tanah Grogot.

Data yang diperoleh penulis dari guru mata pelajaran matematika di sekolah tersebut, nilai rata-rata ulangan semester 1 siswa kelas VIII, masih banyak kelas yang memperoleh nilai di bawah Kriteria Ketuntasan Minimal (KKM) yang ditetapkan oleh sekolah, yaitu 70,00 pada tahun ajaran 2017/2018. Karena kelas VIII-A adalah kelas dengan nilai rata-rata ulangan matematika semester 1 terendah, maka penulis memilih kelas VIII-A sebagai subjek penelitian.

Berdasarkan informasi dari guru matematika kelas VIII di SMP Negeri 5 Tanah Grogot, dalam pembelajaran matematika di sekolah pada umumnya guru men-jelaskan materi, kemudian guru membuat soal untuk murid, dapat dikatakan guru hanya menggunakan model pembelajaran konvensional. Seringkali setelah menerangkan materi guru menanyakan kepada murid, apakah ada yang ingin ditanyakan?, apakah sudah paham?, yang sering terjadi siswa hanya diam dan tersenyum. Namun setelah diberi tugas kebanyakan siswa masih kebingungan bahkan tidak dapat mengerjakannya. Selain itu saat penulis melakukan pengamatan, banyak siswa yang bingung saat menyelesaikan soal walaupun soal tersebut sejenis dengan contoh yang sebelumnya diberikan. Kurangnya latihan soal dan pemahaman konsep yang belum maksimal membuat anak-anak kebingungan dan bahkan tidak dapat menyelesaikan soal. Masalah ini yang mengakibatkan rendahnya hasil belajar siswa di sekolah.

Untuk mengatasi masalah tersebut, guru harus dapat membuat siswa aktif dalam bertanya, karena dengan adanya keaktifan siswa bertanya maka siswa akan mampu memahami tentang pelajaran. Selain itu adanya latihan-latihan soal yang cukup semakin membuat siswa terbiasa dan menambah pemahaman siswa terhadap materi pembelajaran yang sedang berlangsung.

Salah satu upaya untuk mengatasi masalah tersebut, dibutuhkan suatu variasi model pembelajaran maupun strategi pembelajaran. Slameto (dalam Herawati, 2010:71) menyatakan bahwa pembelajaran matematika sangat ditentukan oleh strategi dan pendekatan yang digunakan dalam mengajar matematika itu sendiri. Belajar yang efisien dapat tercapai apabila dapat menggunakan strategi belajar yang tepat. Oleh karena itu guru dituntut untuk professional dalam menjalankan tugasnya. Salah satu model pembelajaran yang dapat digunakan adalah model pembelajaran problem posing. Model pembelajaran problem posing memiliki prinsip yakni pembelajaran yang menekankan dan mewajibkan siswa untuk mengajukan soal sendiri melalui pelajaran soal (berlatih soal secara mandiri).

Model pembelajaran problem posing tipe post solution posing menuntut siswa dapat membuat soal sejenis dan menantang seperti yang dicontohkan oleh guru, selain itu siswa 
juga harus dapat menyelesaikan soal tersebut. Dari model ini diharapkan siswa lebih aktif dan kreatif dalam membentuk pengetahuannya, sehingga pemahaman siswa terhadap konsep matematika lebih baik lagi dan dapat meningkatkan hasil belajar siswa.

Berdasarkan uraian di atas maka penulis bermaksud melakukan penelitian dengan judul sebagai berikut: "Peningkatan Hasil Belajar Matematika Siswa dengan Penerapan Model Pembelajaran Problem Posing di Kelas VIII SMP Negeri 5 Tanah Grogot Tahun Ajaran 2017/2018".

Problem posing adalah istilah dalam bahasa Inggris yaitu dari kata "problem" artinya masalah, soal/persoalan dan kata "pose" yang artinya mengajukan. Jadi, problem posing bisa diartikan sebagai pengajuan soal atau pengajuan masalah. Model pembelajaran problem posing ini mulai dikembangkan ditahun 1997 oleh Lyn D. English, dan awal mulanya diterapkan dalam mata pelajaran matematika. Selanjutnya model ini dikembangkan pula pada mata pelajaran yang lain seperti fisika dan kimia.

Problem posing merupakan
suatu model pembelajaran yang diadaptasikan dengan kemampuan siswa dan dalam proses pembelajarannya membangun struktur kognitif serta dapat memotivasi siswa untuk berpikir kritis dan kreatif. Pada saat model pembelajaran problem posing siswa melakukan hal yang lebih banyak, membentuk asosiasi untuk merumuskan soal dan mengajukan masalah atau soal lebih kreatif dan melakukan pemecahan masalah (problem posing) yang lebih efektif. Merumuskan atau membentuk soal adalah suatu aktivitas dalam pembelajaran yang dapat mengembangkan motivasi dan kemampuan siswa untuk berpikir kritis dan kreatif karena dalam pembelajaran problem posing siswa mendapat pengalaman langsung dalam merumuskan (membentuk soal sendiri).

Kegiatan merumuskan soal akan memberikan kesempatan seluas-luasnya kepada siswa untuk merekonstruksikan pikirannya dan kegiatan ini memungkinkan pembelajaran yang dilakukan siswa lebih bermakna. Model pembelajaran problem posing, siswa diberi kesempatan untuk beraktivitas untuk merumuskan soal dan mendorong siswa agar lebih bertanggung jawab.

Problem posing merupakan model pembelajaran yang mengharuskan siswa menyusun pertanyaan sendiri atau memecah suatu soal menjadi pertanyaan-pertanyaan yang lebih sederhana yang mengacu pada penyelesaian soal tersebut. Dalam pembelajaran matematika, problem posing (pengajuan soal) menempati posisi yang strategis. Siswa harus menguasai materi dan urutan penyelesaian soal secara mendetail. Hal tersebut akan dicapai jika siswa memperkaya pengetahuannya tak hanya dari guru melainkan perlu belajar secara mandiri. Problem posing dikatakan sebagai inti terpenting dalam disiplin matematika (Astra, Umiatin dan Jannah, 2012:137).

Nur Afni (2013:1), Problem posing mempunyai beberapa pengertian yaitu: pertama, problem posing adalah perumusan soal sederhana atau perumusan ulang soal yang ada dengan beberapa perubahan agar lebih sederhana dan dapat dipahami dalam rangka memecahkan soal yang rumit. Kedua, problem posing adalah perumusan soal yang berkaitan dengan syarat-syarat pada soal yang telah dipecahkan dalam rangka mencari alternatif pemecahan lain. Ketiga, problem posing adalah perumusan soal dari informasi atau situasi yang tersedia, 
baik dilakukan sebelum, ketika, atau setelah penyelesaian suatu soal.

Mengenai peranan problem posing dalam pembelajaran matematika, Sutiarso menjelaskan bahwa problem posing adalah suatu bentuk model pembelajaran matematika yang menekankan pada perumus-an soal, yang dapat mengembangkan kemampuan berpikir matematis atau menggunakan pola pikir matematis (dalam Dwyaz, 2012:1).

Model pembelajaran problem posing sangat relevan dengan pembelajaran matematika yang menuntut siswa mempunyai pandangan yang luas dan memiliki sifat yang logis, kritis, cermat, kreatif dan disiplin serta menghargai kegunaan matematika.

Seperti hasil penelitian Silver dan Cai (dalam Surtini, 2004: 48) menunjukkan bahwa kemampuan pembentukan soal berkorelasi positif dengan kemampuan memecahkan masalah. Dengan demikian kemampuan pembentukkan soal sesuai dengan tujuan pembelajaran matematika di sekolah sebagai usaha meningkatkan hasil pembelajaran matematika dan dapat meningkatkan kemampuan siswa. Dari sini diperoleh bahwa pembentukan soal penting dalam pelajaran matematika guna meningkatkan prestasi belajar matematika siswa dengan membuat siswa aktif dan kreatif.

Problem posing dapat dilakukan secara berkelompok atau individu. Secara umum, pengajuan masalah oleh siswa dalam pembelajaran, baik secara kelompok maupun individu merupakan aspek penting. Tingkat pemahaman atau penguasaan siswa terhadap materi yang dipelajarinya dapat dilihat melalui pertanyaan yang diajukannya.

Secara garis besar disimpulkan sintaks model pembelajaran problem posing menurut Amin Suyitno (dalam
Seminar Nasional Lesson Study, 2010:

32) adalah sebagai berikut:

1. Guru mengajarkan materi dan memberikan contoh soal serta latihan.

2. Guru membentuk kelompokkelompok kecil siswa (4-5 siswa). Sebaiknya kelompok ini bersifat heterogen kemampuan akademiknya.

3. Setiap kelompok diminta untuk membuat atau mencari yang berkaitan dengan materi yang diberikan guru (cukup satu soal), dan kelompok yang bersangkutan diminta untuk menemukan sendiri penyelesaiannya

4. Tiap kelompok diminta untuk mempresentasikan soal dan penyelesaiannya.

5. Guru bertindak sebagai fasilitator dan narasumber jika diperlukan.

Berdasarkan beberapa pendapat di atas maka model pembelajaran problem posing dapat diartikan sebagai bentuk model pembelajaran yang menekankan pada kegiatan pengajuan, perumusan atau pembuatan masalah sendiri dan untuk diselesaikan sendiri oleh siswa.

\section{METODE PENELITIAN}

Jenis penelitian yang digunakan dalam penelitian ini adalah penelitian tindakan kelas. Penelitian tindakan kelas dalam istilah bahasa Inggris lebih dikenal dengan Classroom Action Ressearch (CAR). Penelitian tindakan kelas bertujuan untuk meningkatkan mutu proses dan hasil pembelajaran, mengatasi masalah pembelajaran, meningkatkan profesionalisme dan menumbuhkan budaya akademik. Kunandar (dalam Iskandar, 2012:21) mengartikan penelitian tindakan (action ressearch) merupakan suatu kegiatan yang dilakukan oleh guru atau bersamasama dengan orang lain (kolaborasi) 
yang bertujuan untuk memperbaiki atau meningkatkan mutu proses pembelajaran di kelas. Penelitian tindakan kelas merupakan suatu bentuk penelitian dengan menggunakan tindakan-tindakan tertentu, yaitu menggunakan model pembelajaran. Adapun alur dari pelaksanaan penelitian tindakan kelas dapat dilihat pada Gambar 1 berikut:

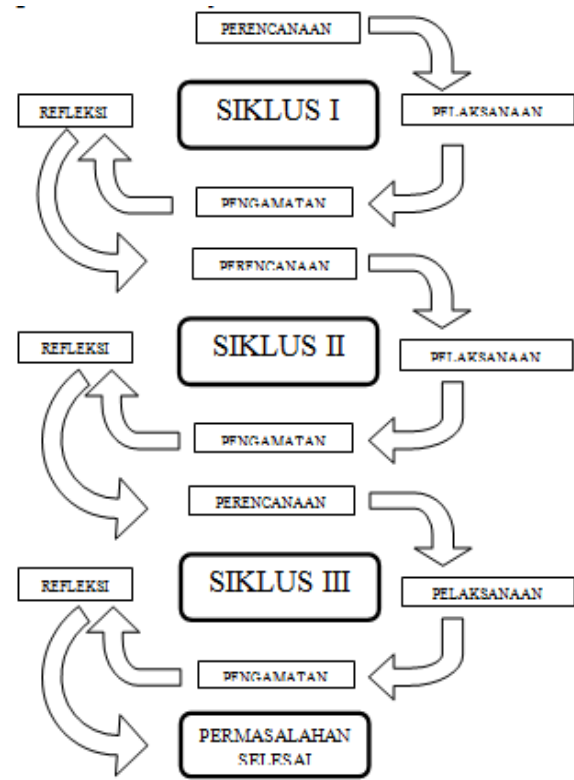

Gambar 1. Alur dalam Penelitian

Tindakan Kelas

(Sumber: Arikunto, 2007:16)

Dengan memperhatikan gambar 3.1 tersebut, penelitian tindakan kelas ini terdiri dari tiga siklus yang dilaksanakan melalui proses pengkajian berulang yang terdiri dari 4 tahapan, yaitu perencanaan, pelaksanaan tindakan yang disertai dengan pengamatan dan refleksi (Iskandar, 2012: 28).

Dalam kegiatan penelitian ini, subyek penelitiannya adalah siswa kelas VIII-A SMP Negeri 5 Tanah Grogot yang berjumlah 35 siswa dan yang menjadi obyek penelitian adalah model pembelajaran problem posing tipe post solution posing pada materi pokok fungsi dan persamaan garis lurus.
Penelitian ini dilaksanakan pada semester I tahun ajaran 2017/2018 yaitu tanggal 9 November sampai dengan 7 Desember di kelas VIII-A SMP Negeri 5 Tanah Grogot, yang beralamat di Jalan RM Noto Sunardi no. 11 Tanah Grogot.

Data penelitian dikumpulkan melalui dokumen, tugas, tes dan observasi. Adapun analisis data yang digunakan adalah analisis data kualitatif dan analisis data kuantitatif. Analisis data kualitatif merupakan analisis yang mengolah dan menganalisis data yang terkumpul menjadi data yang sistematik, teratur dan terstruktur. Pada penelitian ini, data yang diolah secara kualitatif adalah data hasil observasi berlangsungnya proses pembelajaran yang menerapkan pembelajaran problem posing tipe post solution posing. Analisis data kuantitatif merupakan analisis yang berkisar pada masalah pengukuran yang akan dihubungkan dengan angka. Pada penelitian ini data yang dianalisis secara kuantitatif adalah data nilai hasil belajar siswa pada setiap siklusnya.

Indikator keberhasilan dalam penelitian ini adalah apabila guru dapat melaksanakan pembelajaran dengan baik yang diikuti keterlibatan atau partisipasi aktif siswa dalam proses pembelajaran, dan setelah pelaksanaan proses pembelajaran selesai siswa menunjukkan peningkatan terhadap keaktifan belajar, pemahaman materi, dan peningkatan hasil belajar matematika sesuai dengan kriteria ketuntasan minimal yang telah ditentukan. Ketuntasan belajar dinyatakan berhasil jika persentase siswa yang tuntas belajar atau siswa yang mendapat nilai $\geq 70$ jumlahnya mencapai $\geq 80 \%$ dari jumlah seluruh siswa dalam kelas. Untuk mengetahui kriteria hasil belajar siswa yang diperoleh baik atau kurang baik 
digunakan kriteria pada Tabel 1 . berikut:

Tabel 1. Kriteria Hasil Belajar

\begin{tabular}{|c|c|c|}
\hline Rata-rata Nilai & $\begin{array}{c}\text { Nilai } \\
\text { Huruf }\end{array}$ & Kriteria \\
\hline $80 \leq x \leq 100$ & A & Baik Sekali \\
\hline $70 \leq x<80$ & B & Baik \\
\hline $60 \leq x<70$ & C & Cukup \\
\hline $50 \leq x<60$ & D & Kurang \\
\hline $0 \leq x<50$ & E & $\begin{array}{c}\text { Kurang } \\
\text { Sekali }\end{array}$ \\
\hline
\end{tabular}

(Sumber: Sudjana, 2002: 134)

Indikator yang menjadi tolak ukur dalam menyatakan bahwa pembelajaran yang berlangsung selama penelitian berhasil meningkatkan hasil belajar siswa setiap siklus, bila dilihat dari nilai tes hasil belajar yang diadakan pada setiap siklusnya dan dibandingkan dengan nilai dasar maka terjadi peningkatan tiap siklus. Misalnya nilai pada siklus I dibandingkan dengan nilai dasar yang diperoleh dari guru, nilai siklus II dibandingkan dengan nilai pada siklus I, nilai siklus III dibandingkan dengan nilai pada siklus II.

Untuk menentukan poin peningkatan dapat dilihat melalui indikator peningkatan hasil belajar sebagai berikut:

Tabel 2. Kriteria Nilai Peningkatan Hasil Belajar

\begin{tabular}{|c|l|c|}
\hline No & \multicolumn{1}{|c|}{ Skor Kuis Individu } & Poin Kemajuan \\
\hline 1. & $\begin{array}{l}\text { Lebih dari 10 poin di } \\
\text { bawah skor awal }\end{array}$ & 5 Poin \\
2. & $\begin{array}{l}\text { 10 sampai 1 poin di } \\
\text { bawah skor awal }\end{array}$ & 10 Poin \\
3. & $\begin{array}{l}\text { Skor awal sampai 10 } \\
\text { poin di atas skor awal }\end{array}$ & 20 Poin \\
4. & $\begin{array}{l}\text { Lebih dari 10 poin di } \\
\text { atas skor awal }\end{array}$ & 30 Poin \\
5. & $\begin{array}{l}\text { Kertas jawaban } \\
\text { sempurna (terlepas } \\
\text { dari skor awal) }\end{array}$ & 30 Poin \\
\hline
\end{tabular}

(Sumber: Trianto, 2009: 55)
Untuk mengetahui kriteria poin peningkatan siswa yang diperoleh baik atau kurang baik maka digunakan kriteria poin peningkatan yang dapat dilihat dari rata-rata peningkatan seluruh siswa.

Tabel 3. Kriteria Poin Peningkatan Hasil Belajar Siswa

\begin{tabular}{|c|c|}
\hline $\begin{array}{c}\text { Rata-rata Poin } \\
\text { Peningkatan }\end{array}$ & Kriteria \\
\hline$x \geq 25$ & Sangat Baik \\
$20 \leq x<25$ & Baik \\
$15 \leq x<20$ & Cukup \\
$0 \leq x<15$ & Kurang \\
\hline
\end{tabular}

(Sumber: Sukidin, 2002:145)

Selisih rata-rata nilai hasil belajar setiap siswa pada setiap siklus dengan hasil belajar pada siklus sebelumnya dikonversi ke dalam poin peningkatan sesuai dengan Tabel 3 , kemudian poin rata-rata peningkatan yang diperoleh siswa tersebut bertindak sebagai poin hasil belajar secara keseluruhan (kelas). Berdasarkan Tabel 3 , jika poin rata-rata peningkatan seluruh siswa (kelas) adalah dua puluh satu, maka kriteria peningkatan yang terjadi adalah baik. Artinya, peningkatan yang terjadi setelah pembelajaran tergolong baik dari siklus sebelumnya.

Siklus dalam penelitian ini dihentikan jika telah memenuhi indikator sebagai berikut:

1. Tuntas, yaitu apabila minimal $80 \%$ siswa di kelas tersebut memperoleh nilai lebih dari atau sama dengan 70 .

2. Apabila aktivitas siswa dan guru dalam pembelajaran seluruhnya terlaksana dengan baik yang diukur berdasarkan lembar observasi.

HASIL PENELITIAN 
Hasil penelitian yang diperoleh dari penelitian ini meliputi hasil analisis data kualitatif yakni hasil observasi terhadap aktivitas guru dan siswa selama berlangsungnya proses pembelajaran dengan menerapkan model pembelajaran Problem Posing, serta hasil analisis data kuantitatif yakni nilai hasil belajar siswa. Hasil analisis data kualitatif dari keseluruhan siklus berdasarkan hasil observasi aktivitas guru, aktivitas siswa dapat dilihat pada Tabel 4.
Sedangkan untuk hasil analisis data kuantitatif dari keseluruhan siklus berdasarkan hasil belajar dapat dilihat pada Tabel 5.

Tabel 4. Hasil Observasi pada Siklus I, II dan III

\begin{tabular}{|l|c|c|c|}
\hline & Siklus I & $\begin{array}{c}\text { Siklus } \\
\text { II }\end{array}$ & $\begin{array}{c}\text { Siklus } \\
\text { III }\end{array}$ \\
\hline $\begin{array}{l}\text { Aktivitas } \\
\text { Siswa }\end{array}$ & Sangat & Baik & $\begin{array}{c}\text { Sangat } \\
\text { Baik }\end{array}$ \\
\hline $\begin{array}{l}\text { Aktivitas } \\
\text { Guru }\end{array}$ & Cukup & $\begin{array}{c}\text { Sangat } \\
\text { Baik }\end{array}$ & $\begin{array}{c}\text { Sangat } \\
\text { Baik }\end{array}$ \\
\hline
\end{tabular}

(Sumber: Data Hasil Penelitian 2013, Lampiran 56: 309)

Tabel 5. Hasil Belajar pada Siklus I, II dan III

\begin{tabular}{|l|c|c|c|c|c|}
\hline Pelaksanaan & $\begin{array}{c}\text { Nilai } \\
\text { Dasar }\end{array}$ & NT & NA & NH & $\begin{array}{c}\text { Persentase } \\
\text { Peningkatan }\end{array}$ \\
\hline Siklus I & 31,43 & 46,21 & 58,26 & 54,24 & $72,57 \%$ \\
\hline Siklus II & 54,24 & 72,93 & 64,71 & 67,45 & $24,35 \%$ \\
\hline Siklus III & 67,45 & 72,00 & 73,26 & 72,84 & $7,99 \%$ \\
\hline
\end{tabular}

(Sumber: Data Hasil Penelitian 2013, Lampiran 56: 309)

Pada Tabel 5 dijelaskan bahwa pembelajaran yang dilakukan tiap siklus meningkatkan hasil belajar matematika siswa. Rata-rata hasil belajar matematika siswa pada nilai awal sebelum menggunakan model pembelajaran problem posing tipe post solution posing sebesar 31,43 dan pada siklus I meningkat menjadi 54,24 dengan kriteria kurang atau meningkat sebesar 72,57\%; pada siklus II meningkat menjadi 67,45 dengan kriteria cukup atau meningkat sebesar 24,35\%; dan pada siklus III meningkat menjadi 72,84 dengan kriteria baik atau $7,99 \%$. Selain itu persentase siswa yang mencapai ketuntasan mengalami peningkatan, pada siklus I sebesar

$11,43 \%$ siswa yang mencapai nilai KKM, meningkat pada siklus II sebesar $54,28 \%$ siswa kemudian pada siklus III meningkat menjadi $82,86 \%$ siswa yang mencapai nilai KKM.

\section{PEMBAHASAN}

Berdasarkan hasil penelitian yang diperoleh selama proses pembelajaran, terlihat bahwa data telah sesuai dengan indikator dan format panduan observasi. Sebelum melaksanakan proses pembelajaran problem posing tipe post solution posing terlebih dahulu siswa diperkenalkan mengenai model pembelajaran tersebut. Karena model pembelajaran yang akan diterap-kan berbeda dengan model pembelajaran yang biasa mereka lakukan di kelas, melainkan suatu kegiatan yang menekankan agar siswa dapat mengajukan masalah (dalam hal ini membuat soal) beserta jawabannya seperti yang telah guru contohkan sebelum-nya, dan dilakukan secara kelompok. 
Dari hasil penelitian dan pembahasan pada setiap siklus, pembelajaran dengan model problem posing tipe post solution posing yang dilakukan tiap siklus mempengaruhi hasil belajar siswa yaitu terjadi peningkatan hasil belajar matematika siswa. Hal ini terlihat dari hasil tugas kelompok siswa yang menunjukkan semakin tinggi nilai tugas kelompok, maka semakin tinggi pula mendapatkan nilai hasil belajar, dengan syarat semua siswa berperan aktif dalam penyelesaian tugas kelompok. Selain itu dalam kegiatan pembelajaran setiap siklus aktivitas guru maupun aktivitas siswa juga mengalami peningkatan.

Dalam proses pembelajaran dengan menggunakan model pembelajaran problem posing tipe post solution posing, guru bertindak sebagai fasilitator sedangkan siswa dituntut lebih aktif dalam mengembangkan pengetahuan mereka yaitu dengan mengajukan soal dan penyelesaiannya. Peran guru disini yaitu membuat siswa memahami konsep dan mengetahui target yang akan dicapai dalam proses pembelajaran. Tahap selanjutnya, guru memberikan kesempatan siswa yang telah diatur berkelompok untuk mengajukan soal beserta penyelesaiannya sesuai dengan contoh yang telah diberikan, inilah yang disebut bentuk problem posing tipe post solution posing menurut Silver (dalam Thobroni dan Arif, 2011:352). Dalam kegiatan kelompok, siswa harus saling bekerjasama dan berdiskusi dalam menyelesaikan tugas. Setelah itu, guru menunjuk salah satu perwakilan kelompok untuk menuliskan dan mempresentasikan hasil dari diskusi kelompok mereka di depan kelas. Sedangkan siswa lainnya memperhatikan jawaban dan memberikan tanggapan, bertanya dan menyanggah jawaban yang dipresentasikan jika perlu. Hal ini efektif untuk meningkatkan tanggung jawab setiap siswa terhadap hasil dari diskusi kelompok mereka, sekaligus melatih kemampuan individu siswa untuk menyampaikan pendapat. Dengan adanya keterlibatan seluruh siswa, tentunya berdampak positif terhadap motivasi belajarnya. Langkah-langkah yang telah dilakukan dalam proses pembelajaran sesuai dengan yang telah dikemukakan oleh A. Suyitno (2010:30) maupun oleh A. Pamurti (2013:12).

Secara keseluruhan adapun kegiatan-kegiatan yang dilakukan siswa dalam model pembelajaran problem posing tipe post solution posing yakni, siswa dibiasakan belajar aktif secara individu dan kelompok, siswa dapat saling bertukar informasi dan pendapat, siswa menjadi lebih bertanggung jawab baik secara individu dan kelompok serta menambah kepercayaan diri siswa dalam mengungkapkan ide-ide maupun gagasan. Hal ini sesuai dengan teori yang dikemukakan oleh Skinner (dalam Isriani dan Dewi, 2011:4) yang mengemukakan bahwa belajar adalah suatu proses adaptasi atau penyesuaian tingkah laku yang berlangsung secara progresif. Dalam hal ini proses belajar dengan menerapkan model pembelajaran problem posing tipe post solution posing dapat meningkatkan hasil belajar dari segi kognitif maupun afektif. Keberhasilan peningkatan hasil belajar siswa ini ditunjang juga oleh proses pembelajaran yang terlaksana di dalam kelas, yaitu motivasi yang diberikan guru kepada siswa dan penyampaian persepsi baik tentang matematika agar siswa menjadi lebih termotivasi dalam belajar matematika.

Berdasarkan pembahasan di atas yang didukung dengan teori-teori yang ada, maka dapat dijelaskan bahwa hipotesis tindakan dapat diterima yang berarti hasil belajar siswa dapat 
ditingkatkan dengan penerapan model pembelajaran problem posing tipe post solution posing pada materi pokok fungsi dan persamaan garis lurus di kelas VIII-A SMP Negeri 5 Tanah Grogot tahun ajaran 2017/2018.

\section{KESIMPULAN}

Dari hasil penelitian tindakan kelas yang telah dilaksanakan dapat disimpulkan bahwa model pembelajaran problem posing tipe post solution posing dapat meningkatkan hasil belajar matematika pada materi pokok fungsi dan persamaan garis lurus siswa kelas VIII-A SMP Negeri 5 Tanah Grogot tahun ajaran 2017/2018.

Nilai rata-rata siswa setelah melaksanakan pembelajaran dengan meng-gunakan model pembelajaran problem posing tipe post solution posing mengalami peningkatan pada setiap siklus. Pada siklus I nilai rata-rata meningkat sebesar $72,57 \%$ dari nilai dasar yaitu 31,43 menjadi 54,24. Pada siklus II meningkat sebesar $24,35 \%$ dari siklus I yaitu 54,24 menjadi 67,45. Dan pada siklus III terjadi peningkatan sebesar 7,99\% dari siklus II yaitu 67,45 menjadi 72,84 .

Persentase ketuntasan juga mengalami peningkatan setelah pembelajaran menggunakan model pembelajaran problem posing tipe post solution posing, pada siklus I persentase ketuntasan siswa sebesar $11,43 \%$ atau sebanyak 4 siswa yang mencapai nilai KKM. Pada siklus II meningkat menjadi 54,28\% atau sebanyak 19 siswa yang mencapai nilai KKM, dan pada siklus III meningkat menjadi $82,86 \%$ atau sebanyak 29 siswa yang mencapai nilai KKM.

Hasil observasi terhadap aktivitas guru dan siswa juga mengalami peningkatan. Pada siklus I aktivitas guru dinilai cukup. Pada siklus II dan III aktivitas guru dinilai sangat baik. Sedangkan aktivitas siswa pada siklus I dinilai sangat kurang, namun pada siklus II dinilai baik dan siklus III dinilai sangat baik.

\section{DAFTAR PUSTAKA}

Afni, N. 2013. Problem Posing. Diakses tanggal 21 Oktober 2013 dari http://nurafhny.blogspot.com/2 013/04/ problem-posing.html/.

Arikunto, S. 2007. Penelitian Tindakan Kelas. Jakarta: Bumi Aksara.

Astra, M, Umiatin dan Jannah. 2012. Pengaruh Model Pembelajaran Problem Posing tipe Pre Solutian Posing Terhadap Hasil Belajar Fisika dan Karakter Siswa SMA. Jurnal Pendidikan Fisika Indonesia. Universitas Negeri Jakarta.

Dwyaz. 2012. Problem Posing dalam Pembelajaran Matematika. Diakses tanggal 5 Mei 2013 dari

http://dwyaza.weebly.com/pro blem-posing-dalampembelajaranmatematika.html/.

Herawati, 2010. Pengaruh

Pembelajaran Problem Posing Terhadap kemampuan Pemahaman Konsep Matematika Siswa Kelas XI IPA SMA Negeri 6 Palembang. Jurnal Pendidikan Matematika. Unsri.

Iskandar. 2012. Penelitian Tindakan Kelas. Ciputat: Referensi.

Isriani dan Dewi. 2011. Strategi Pembelajaran Terpadu (Teori, Konsep \& Implementasi). Yogyakarta: Familia.

Pramudjono. 2008. Statistik Dasar. Samarinda: FKIP Universitas Mulawarman.

Rahaju, $\begin{array}{cr}\text { E.B. } 2008 . & \text { Contextual } \\ \text { Teaching and Learning }\end{array}$ 
Matematika

Sekolah

Menengah Pertama Kelas VIII

Edisi 4. Jakarta: Pusat

Perbukuan Dinas Pendidikan

Nasional.

Saiful, A. 2012. Problem Posing. Diakses tanggal 5 mei 2013 dari

http://pakgurusaiful.blogspot.co $\underline{\mathrm{m} / 2012 / 07 / \text { metode-problem- }}$ posing.html.

Salim, A. 2013. Pengertian Hakikat Matematika. Diakses tanggal 22 Oktober 2013 dari http://asbarsalim009.blogspot. com/2013/10/pengertanhakikat-matematika.html/.

Shidiq, A. 2011. Problem Posing dalam Pembeljaran Matematika. Diakses tanggal 21 Oktober 2013 dari http://achmadbluee.blogspot.c om/2011/05/ problem-posingdalam-pelajaran.html/.

Slavin, R.E. 2009. Cooperative Learning Teori, Riset, dan Praktik. Bandung: Nusamedia.

Soedjadi. 2000. Kiat Pendidikan di Indonesia. Konstatasi Keadaan Masa Kini Menuju Hari Harapan Masa Depan. Jakarta: Dirjrndikti DEPDIKNAS.

Sudjana, N. 2010. Penilaian Hasil Proses Belajar Mengajar. Bandung: Remaja Rosdakarya.

Sukidin, Basrowi, dan Suranto. 2002. Manajemen Penelitian Tindakan Kelas. Jakarta: Insan Cendikia.

Sukino dan Simangunsong, W. 2007. Matematika untuk SMP Kelas VIII. Jakarta: Erlangga.

Surtini, S. 2004. Problem Posing dan Pembelajaran Operasi Hitung Bilangan Cacah Siswa SD. Jurnal Pendidikan. Diakses tanggal 29 Juni 2013 dari http://matematikaunhalu. files.wordpress.com/2009/03/.

Suyitno, Amin. 2010. Menggabungkan Model Pembelajaran Problem Posing dan Mind Mapping yang Dikemas dalam Kegiatan Lesson Study untuk Meningkatkan Aktivitas Belajar dan Daya Serap Siswa Dalam Belajar Matematika. Semarang: Seminar Nasional Lesson Study.

Thobroni, M dan Arif M. 2011. Belajar \& Pembelajaran. Yogyakarta: Ar-Ruzz Media.

Trianto. 2009. Mendesain Model Pembelajaran Inovatif Progresif, Konsep, Landasan dan Implementasinya Pada Kurikulum Tingkat Satuan Pendidikan (KTSP). Jakarta: Kencana. 2012. Panduan Lengkap Penelitian Tindakan Kelas (Classroom Action Research) Teori dan Praktik. Jakarta: Prestasi Pustaka. 